\title{
The Relationship of AMH Level with Ovarian Response in PCOS Patients
}

Dr. Iffana Azam ${ }^{1 *}$, Dr. Shahana Ferdous Choudhury ${ }^{2}$, Dr. Natia Rahnuma ${ }^{3}$

${ }^{1}$ Assistant Professor, Department of Gynae \& Obs, Sylhet Women's Medical College \& Hospital, Bangladesh

${ }^{2}$ Professor and Head, Department of Gynae \& Obs, Sylhet Women's Medical College \& Hospital, Bangladesh

${ }^{3}$ Assistant Professor, Department of Gynae \& Obs, Jalalabad Ragib-Rabeya Medical College \& Hospital, Bangladesh

DOI: $10.36347 /$ sjams.2021.v09i02.013

| Received: 03.02.2021 | Accepted: 16.02.2021 | Published: 23.02.2021

*Corresponding author: Dr. Iffana Azam

Abstract

Original Research Article

Introduction: Polycystic ovary syndrome (PCOS) is the most common endocrine disorder of women of reproductive age. Anti-Mullerian hormone (AMH) has a glycoprotein dimer structure and is a member of the transforming growth factor- $\beta$ (TGF- $\beta$ ) family. AMH is produced by the granulosa cells surrounding preantral and antral follicles and has an important role in the development and maturation of follicles. Several studies have suggested that AMH serum levels may be a marker for polycystic ovary syndrome (PCOS). Serum AMH has also demonstrated its utility in the treatment of infertility. Objective: To assess relationship of AMH level with ovarian response in Polycystic Ovary Syndrome (PCOS) patients. Methods: This is a cross sectional comparative study which was held at Sylhet women's Medical college from 2018 to 2019. Result: In this study 45 respondent had participated. For statistical analysis of this study AMH divided by two sub groups Group A $(<8)$ and Group B $(8<)$ and study found that $50.7 \%$ respondent had AMH which is Group A $(<8)$. This study also revealed the negative correlation between AMH and follicle size $(r=-$ 0.288). On other hand AMH Group have positive correlation between LH $(r=0.238$. Besides follicle size have positive correlation with ET ( $\mathrm{r}=0.044)$ which is statistically significant. Conclusion: From this study it is easily understandable that AMH plays an important role to predict ovarian response to ovulation education in Polycystic Ovary Syndrome (PCOS) patients.

Keywords: Polycystic ovary syndrome (PCOS), Anti-Mullerian hormone (AMH), Ovarian response.

Copyright $(\mathcal{C}) 2021$ The Author(s): This is an open-access article distributed under the terms of the Creative Commons Attribution 4.0 International License (CC BY-NC 4.0) which permits unrestricted use, distribution, and reproduction in any medium for non-commercial use provided the original author and source are credited.

\section{INTRODUCTION}

Polycystic ovary syndrome (PCOS) is among the primary causes of infertility due to anovulation, with a prevalence rate of $4 \%-6 \%$ in women of reproductive age.

PCOS is almost certainly a genetic condition but the precise causes of hyperandrogenism and anovulation, are still under investigations. AntiMullerian hormone $(\mathrm{AMH})$ has a glycoprotein dimer structure and is a member of the transforming growth factor- $\beta$ (TGF- $\beta$ ) family. AMH is produced by the granulosa cells surrounding preantral and antral follicles and has an important role in the development and maturation of follicles $[1,2]$.

Several studies have suggested that AMH serum levels may be a marker for polycystic ovary syndrome (PCOS). The level of AMH circulating in the blood is not affected by the menstrual cycle nor altered during the use of oral contraceptives, therefore it can be used as a potential biochemical marker for PCO or PCOS. Serum AMH has also demonstrated its utility in the treatment of infertility. But the absence of an international standard for serum $\mathrm{AMH}$ assay and the inability to define thresholds makes application of serum AMH more difficult. AMH has been predominantly known for its role in male sexual differentiation. In women, AMH expression is restricted to one cell type: the granulosa cells of the ovary. It starts around the 25 th week of gestation continuing until menopause.

Serum AMH levels in women with PCOS are 2- to 3-fold higher than in ovulatory women with normal ovaries, which corresponds to the 2- to 3-fold increase in the number of small follicles seen in PCOS. The increased AMH has been hypothesized may reduce follicle sensitivity to FSH and estradiol production, thus preventing follicle selection, resulting in follicle arrest at the small antral phase with the failure of dominance $[3,4]$. 
Normal AMH level is over $1 \mathrm{ng} / \mathrm{ml}$. Though 2 to $4 \mathrm{ng} / \mathrm{ml}$ is considered normal but more than $3 \mathrm{ng} / \mathrm{ml}$ is an indicator for PCOS. A serum level of AMH >5 $\mathrm{ng} / \mathrm{ml}$ is suggested to be the most sensitive and specific diagnostic marker for PCOS. Below $1 \mathrm{ng} / \mathrm{ml}$ is considered low. In between 5 to $7 \mathrm{ng} / \mathrm{ml}$ is high normal [5].

A linear relationship between the serum AMH level and ovarian response is well-known in fully stimulated IVF cycles in normo ovulatory women. This suggests increased serum AMH levels in PCOS would also reflect an intrinsic dysregulation of the granulosa cells, in which AMH, itself, could be involved since an over expression of the AMH receptor type II (AMHRII) has also been demonstrated. The cause of such high production of $\mathrm{AMH}$ in antral follicles from $\mathrm{PCO}$ is currently unknown, but there is evidence to support a role played by androgens. Indeed, a positive correlation between serum androgen and AMH levels has been reported and the over production of androgens could be an intrinsic defect of thecal cells in PCOS Studies demonstrated contradictory results concerning $\mathrm{AMH}$ regulation by gonadotropins. For some authors, gonadotropins (especially $\mathrm{FSH}$ ) inhibit serum $\mathrm{AMH}$ production in vivo in normal ovaries. On the contrary, others demonstrated a stimulating effect of FSH on $\mathrm{AMH}$ expression in normal ovaries as well as in PCOS. The recent finding that E2 inhibits $\mathrm{AMH}$ expression could reconcile those different results. FSH may directly stimulate $\mathrm{AMH}$ in small antral follicles, as long as they do not express aromatase. But in larger follicles, by increasing E2 Polycystic ovary syndrome (PCOS) is the most common endocrine disorder of women of reproductive age [5-7].

Serum AMH levels in women with PCOS are 2- to 3-fold higher than in ovulatory women with normal ovaries. Which corresponds to the 2- to 3-fold increase in the number of small follicles seen in PCOS. The increased AMH has been hypothesized may reduce follicle sensitivity to FSH and estradiol production, thus preventing follicle selection, resulting in follicle arrest at the small antral phase with the failure of dominance [8].

Normal AMH level is over $1 \mathrm{ng} / \mathrm{ml}$. Though 2 to $4 \mathrm{ng} / \mathrm{ml}$ is considered normal but more than $3 \mathrm{ng} / \mathrm{ml}$ is an indicator for PCOS. A serum level of $\mathrm{AMH}>5$ $\mathrm{ng} / \mathrm{ml}$ is suggested to be the most sensitive and specific diagnostic marker for PCOS. Below $1 \mathrm{ng} / \mathrm{ml}$ is considered low. In between 5 to $7 \mathrm{ng} / \mathrm{ml}$ is high normal.

A linear relationship between the serum AMH level and ovarian response is well-known in fully stimulated IVF cycles in normo ovulatory women. This suggests increased serum AMH levels in PCOS would also reflect an intrinsic dysregulation of the granulosa cells, in which AMH, itself, could be involved since an over expression of the AMH receptor type II (AMHRII) has also been demonstrated. The cause of such high production of AMH in antral follicles from PCO is currently unknown, but there is evidence to support a role played by androgens. Indeed, a positive correlation between serum androgen and AMH levels has been reported and the over production of androgens could be an intrinsic defect of thecal cells in PCOS $[9,10]$.

In this study our main goal is to evaluate the relationship of AMH level with ovarian response in PCOS patients.

\section{OBJECTIVE}

To assess the relation of AMH level with ovarian response to ovulation induction with Clomiphene Citrate in Polycystic Ovary Syndrome (PCOS) patients.

\section{Method ANd Materials}

Study design: Cross sectional comparative study.

Study period and place: This study was carried out at Sylhet women's Medical college from 2018 to 2019.

\section{Study Population}

Diagnosis of PCOS was done according to 2003, Rotterdam Revised diagnostic criteria. Study participants was selected from the patients attending the Reproductive Endocrinology and Infertility OPD clinic at Sylhet women's Medical college. Those PCOS women with $\mathrm{AMH}$ level $<8 \mathrm{ng} / \mathrm{dl}$ will be in group-A and $\mathrm{AMH}$ level $\geq 8 \mathrm{ng} / \mathrm{dl}$ will be in group-B.

Sampling Method: Purposive sampling

\author{
Variables \\ Independent Variable \\ - Age \\ - Education \\ - BMI \\ - Serum AMH level
}

\section{Dependent or outcome variable}

Ovarian response (follicle size \& ET)

Confounding variables, if applicable: LH level

Sample size measurement: Sample size and the statistical basis of it

Sample size determination: To determine the sample size, Wilcoxon Test (Normal Distribution) was followed:

Sample size was determined by the following formula:

Sample size is determined by

$$
\mathrm{n}=\frac{(u+v)^{2}\left(\sigma_{1}^{2}+\sigma_{0}^{2}\right)}{\left(\mu_{1}-\mu_{0}\right)^{2}}
$$


$\mathrm{u}=1.96$ (95\% level type 1 error)

$\mathrm{v}=0.42$ (80\% level type 2 error)

$\sigma_{1}=1.97\left[\sigma_{1}=\mathrm{SD}\right.$ of one group: from previous study]

$\sigma_{0}=3.49\left[\sigma_{0}=\mathrm{SD}\right.$ of other group: from previous study]

$\mu_{1}=5.34\left[\mu_{1}=\right.$ mean of one group: from previous study]

$\mu_{0}=7.81\left[\mu_{0}=\right.$ mean of other group: from previous study]

Mean $\left(\mu_{1} \& \mu_{0}\right)$ and standard deviation $\left(\sigma_{1} \& \sigma_{0}\right)$

So, sample size $=20.66=21$ (for each group)

So ultimate sample size $=42$.Upto $10 \%$ patients may be drop out. So, we have taken 50 subjects reasonably.

Ref: Xi et al., Journal of Ovarian Research (2016) 9:3

DOI 10.1186/s13048-016-0214-

\section{INCLUSION AND EXCLUSION CRITERIA \\ Inclusion Criteria}

- Diagnosed case of PCOS patients according to Rotterdam criteria.

- Age 18 to 35 years.

- Has given consent to participate in the study.

- $\quad$ BMI less than $30 \mathrm{KG} / \mathrm{M}^{2}$

- Normal semen parameter

- At least three follow up visit will be needed, one visit for $\mathrm{AMH}$ assay, one for ovulation induction and one for folliculometry.

\section{Exclusion Criteria}

- Age more than 35 years

- Bilateral tubal block

- Endometriosis

- Male infertility (azoospermia, oligozoospermia)

- Hyperprolactinemia

- Uncontrolled hypothyroidism

- Uncontrolled DM

- Uncontrolled Hypertension

Data analysis: A semi-structured, pre-tested and modified questionnaire designed was used to collect the information. All the data were entered and analyzed by using Statistical Package for Social Science (SPSS-23).

\section{RESULTS}

In Table-1 showed the age distribution of the patients. The mean age of the patients is 28.200 and minimum and maximum age range was 21 and 38 (respectively). The following table is given below in detail:

Table-1: Distribution of age of the patients $(\mathrm{N}=45)$

\begin{tabular}{|l|l|l|l|l|l|}
\hline Descriptive Statistics & N & Minimum & Maximum & Mean & Std. Deviation \\
\hline Age in year & 45 & 21.0 & 38.0 & 28.200 & 3.4351 \\
\hline Valid N (listwise) & 45 & & & & \\
\hline
\end{tabular}

In Table-2 shows distribution of the study populations by demographic characteristic where in both group most of the patients belong to 25 to 29 years age group. Also, maximum patients coming from urban area. The following table is given below in detail:

Table-2: Distribution of the study populations by demographic characteristic $(n=45)$

\begin{tabular}{|c|c|c|c|c|c|}
\hline \multirow[t]{2}{*}{ Social Demographic Characteristics } & \multicolumn{2}{|c|}{ Group A $(<8)$} & \multicolumn{2}{|c|}{ Group B $(8<)$} & \multirow[t]{2}{*}{ P Value } \\
\hline & $\mathbf{N}$ & $(\%)$ & $\mathbf{N}$ & $(\%)$ & \\
\hline \multicolumn{6}{|l|}{ Age (in Years) } \\
\hline $20-24$ & 4 & $11.8 \%$ & 1 & $9.1 \%$ & \multirow[t]{5}{*}{0.843} \\
\hline $25-29$ & 17 & $50.0 \%$ & 7 & $63.6 \%$ & \\
\hline $30-34$ & 12 & $35.3 \%$ & 3 & $27.3 \%$ & \\
\hline $35-39$ & 1 & $2.9 \%$ & 0 & $0.0 \%$ & \\
\hline Total & 34 & $100.0 \%$ & 11 & $100.0 \%$ & \\
\hline \multicolumn{6}{|l|}{ Occupation } \\
\hline Student & 3 & $9.7 \%$ & 1 & $9.1 \%$ & \multirow[t]{4}{*}{0.724} \\
\hline Housewife & 22 & $71 \%$ & 9 & $81.8 \%$ & \\
\hline Service & 6 & $19.4 \%$ & 1 & $9.1 \%$ & \\
\hline Total & 31 & $100 \%$ & 11 & $100 \%$ & \\
\hline \multicolumn{6}{|l|}{ Residence } \\
\hline Urban & 24 & $75 \%$ & 9 & $81.8 \%$ & \multirow[t]{3}{*}{0.644} \\
\hline Rural & 8 & $25 \%$ & 2 & $18.2 \%$ & \\
\hline Total & 32 & $100 \%$ & 11 & $100 \%$ & \\
\hline $\begin{array}{r}\mathrm{Ns}= \\
\text { P value reached from } \mathrm{u} \\
\mathrm{P} \text { value reach } \\
\text { Group A= PCOS pa } \\
\text { Group B=PCOS pat }\end{array}$ & $\begin{array}{l}\text { sign } \\
\text { aired } \\
\text { from } \\
\text { ats w } \\
\text { its wh }\end{array}$ & $\begin{array}{l}\text { icant } \\
\text { test in quan } \\
\text { Chi-square t } \\
\text { ose AMH le } \\
\text { se AMH le }\end{array}$ & $\begin{array}{l}\text { tative } \\
\mathrm{el} \text { is } \\
\mathrm{l} \text { is }>\end{array}$ & lata & \\
\hline
\end{tabular}


In Figure-1 shows frequency distribution of group AMH where all PCOS women $50.7 \%$ population had AMH level below $<8 \mathrm{ng} / \mathrm{ml}$ belong to Group A and
$15.9 \%$ population belong to Group B $(\geq 8 \mathrm{ng} / \mathrm{ml}))$. The total mean of AMH is $6.56 \mathrm{ng} / \mathrm{ml}$. Mean SD was 5.87 . The following figure is given below in detail:

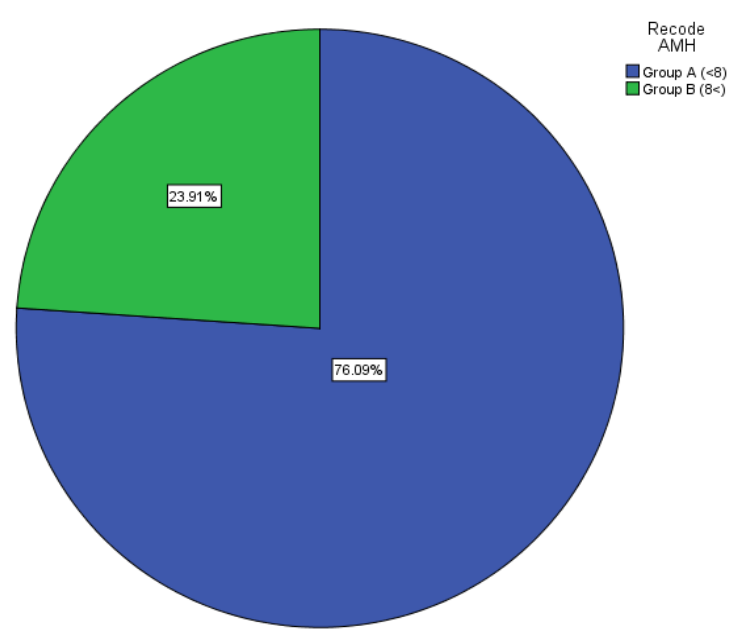

Fig-1: Frequency distribution of group AMH

Table-3 shows the distribution of the study populations by clinical characteristics was observed that more than half $55.6 \%$ in group A and $63.6 \%$ in group B populations had primary subfertility. According to BMI level more than $74.2 \%$ in group A and $60 \%$ in group B were overweight. In Group A $19.4 \%$ were obese and $30 \%$ were obese in Group B. According to hirsutism FG score more than $70 \%$ had more than $60 . T$ he difference was not $(\mathrm{p}>0.05)$ statistically significant.

Table-3: Distribution of the study populations by clinical characteristics $(n=45)$

\begin{tabular}{|c|c|c|c|c|c|}
\hline \multirow[t]{2}{*}{ Clinical Characteristics } & \multicolumn{2}{|c|}{ Group A $(<8)$} & \multicolumn{2}{|c|}{ Group B $(8<)$} & \multirow[t]{2}{*}{ P Value } \\
\hline & $\mathbf{N}$ & $(\%)$ & $\mathbf{N}$ & $(\%)$ & \\
\hline \multicolumn{6}{|l|}{ Types of Infertility } \\
\hline Primary & 15 & $55.6 \%$ & 7 & $63.6 \%$ & \multirow[t]{3}{*}{0.647} \\
\hline Secondary & 12 & $44.4 \%$ & 4 & $36.4 \%$ & \\
\hline Total & 27 & $100 \%$ & 11 & $100 \%$ & \\
\hline \multicolumn{6}{|l|}{ BMI (Body Mass Index kg/m²) } \\
\hline Normal Range $\left(18.5-24.9 \mathrm{~kg} / \mathrm{m}^{2}\right)$ & 2 & $6.5 \%$ & 1 & $10 \%$ & \multirow[t]{4}{*}{$0 . .692$} \\
\hline Overweight $\left(25-29.9 \mathrm{~kg} / \mathrm{m}^{2}\right)$ & 23 & $74.2 \%$ & 6 & $60 \%$ & \\
\hline Obese $\left(>30 \mathrm{~kg} / \mathrm{m}^{2}\right)$ & 6 & $19.4 \%$ & 3 & $30 \%$ & \\
\hline Total & 29 & $100 \%$ & 10 & $100 \%$ & \\
\hline \multicolumn{6}{|l|}{ Modified FG Score } \\
\hline$>6$ & 7 & $29.2 \%$ & 3 & $30 \%$ & \multirow[t]{3}{*}{0.961} \\
\hline $6>$ & 17 & $70.8 \%$ & 7 & $70 \%$ & \\
\hline Total & 24 & $100 \%$ & 10 & $100 \%$ & \\
\hline
\end{tabular}

In Table-4 shows correlation between BMI and follicle. BMI and follicle size are positively correlated but not significance, here $\mathrm{P}>0.05$. The following table is given below in detail:

Table-4: Correlation between BMI and follicle

\begin{tabular}{|l|l|l|l|}
\hline \multicolumn{2}{|l|}{} & BMI & Follicle Size \\
\hline \multirow{5}{*}{ BMI } & Pearson Correlation & 1 & .027 \\
\cline { 2 - 4 } & Sig. (2-tailed) & & .867 \\
\cline { 2 - 4 } & $\mathrm{N}$ & 41 & 41 \\
\hline \multirow{5}{*}{ Follicle Size } & Pearson Correlation & .027 & 1 \\
\cline { 2 - 4 } & Sig. (2-tailed) & .867 & \\
\cline { 2 - 4 } & $\mathrm{N}$ & 41 & 46 \\
\hline
\end{tabular}

$\mathrm{BMI}$ and follicle size are positively correlated but not significance, here $\mathrm{P}>0.05$. 
In Table-5 shows regression analysis between Serum LH, Serum AMH, BMI where $\mathrm{R}$ denotes the correlation between predicted and observed serum LH. In our case, $\mathrm{R}=0.390$. Since this is a positive correlation, our model predicts serum LH rather precisely. $\mathrm{R}$ square indicates the proportion of variance in Serum LH that can be "explained" by our two predictors. Here $\mathrm{R}$ square is 0.152 . The adjusted $\mathrm{r}$ square estimates the population $\mathrm{R}$ square for our model and thus gives a more realistic indication of its predictive power. Here adjusted R square is 0.106 .

Table-5: Regression analysis between Serum LH, Serum AMH, BMI

\begin{tabular}{|l|l|l|l|l|}
\hline \multicolumn{4}{|l|}{ Model Summary } \\
\hline Model & R & R Square & Adjusted R Square & Std. Error of the Estimate \\
\hline 1 & $.390^{\mathrm{a}}$ & .152 & .106 & 4.74844 \\
\hline
\end{tabular}

In Table-6 shows distribution of frequency of Follicle Size with respect to AMH Group. Where mean follicle size in Group A was 19.5 where as in Group B it was 28.3. The following table is given below in detail:

\section{Table-6: Distribution of frequency of Follicle Size} with respect to AMH Group.

\begin{tabular}{|l|l|l|l|}
\hline \multirow{2}{*}{ AMH Group } & \multicolumn{3}{|l|}{ Follicle Size } \\
\cline { 2 - 4 } & $\mathrm{N}$ & Mean & Stdv. \\
\hline Group A $(<8)$ & 35 & 19.5 & 3.00 \\
\hline Group B $(8<)$ & 12 & 28.3 & 3.60 \\
\hline
\end{tabular}

In Table-7 shows correlation between AMH and follicle size. Correlation of AMH with itself $(r=1)$, and the number of nonmissing observations for height $(n=46)$. Correlation of AMH and Follicle Size $(r=$ 0.288 ), based on $\mathrm{n}=46$ observations with pairwise nonmissing values. AMH and Follicle Size have a statistically significant linear relationship $(r=-0.288, p$ $\leq 0.05)$. The direction of the relationship is negative meaning that these variables tend to decrease when serum AMH increase. The following table is given below in detail:

Table-7: Correlation between AMH and Follicle size.

\begin{tabular}{|l|l|l|l|}
\hline \multicolumn{2}{|l|}{ Correlations } & AMH & Follicle Size \\
\hline \multirow{4}{*}{ AMH } & Pearson Correlation & 1 & -.288 \\
\cline { 2 - 4 } & Sig. (2-tailed) & & .052 \\
\cline { 2 - 4 } & $\mathrm{N}$ & 46 & 46 \\
\hline \multirow{4}{*}{ Follicle Size } & Pearson Correlation & -.288 & 1 \\
\cline { 2 - 4 } & Sig. (2-tailed) & .052 & \\
\cline { 2 - 4 } & $\mathrm{N}$ & 46 & 46 \\
\hline
\end{tabular}

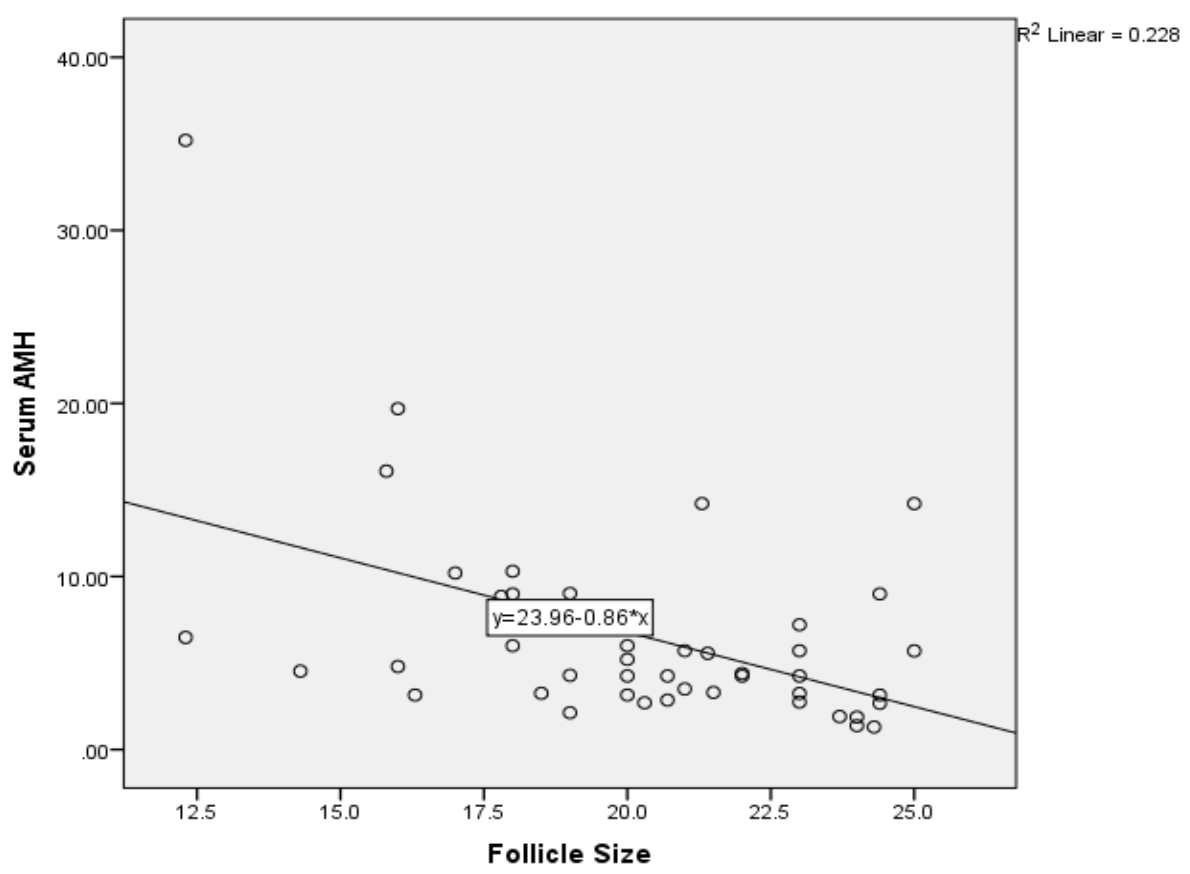

Fig-2: Scatter plot of Serum AMH and Follicle Size 
Iffana Azam et al; Sch J App Med Sci, Feb, 2021; 9(2): 241-247

In Table- 8 shows correlation of AMH with itself $(\mathrm{r}=1)$, and the number of nonmissing observations $(n=46)$. Correlation of AMH and LH $(r=0.238)$, based on $n=46$ observations with pairwise nonmissing values.
$\mathrm{AMH}$ and $\mathrm{LH}$ have not a statistically significant linear relationship ( $\mathrm{r}=0.238, \mathrm{p} \geq 0.05)$. The following table is given below in detail:

Table-8: Correlation between AMH and LH

\begin{tabular}{|c|c|c|c|}
\hline \multicolumn{4}{|l|}{ Correlations } \\
\hline & & Serum AMH & Serum LH \\
\hline \multirow[t]{3}{*}{ Serum AMH } & Pearson Correlation & 1 & .238 \\
\hline & Sig. (2-tailed) & & .116 \\
\hline & $\mathrm{N}$ & 46 & 45 \\
\hline \multirow[t]{3}{*}{ Serum LH } & Pearson Correlation & .238 & 1 \\
\hline & Sig. (2-tailed) & .116 & \\
\hline & $\mathrm{N}$ & 45 & 45 \\
\hline
\end{tabular}

\section{Discussion}

In this study, information has been collected from 46 patients. Here all the respondents was female. The mean age between $28.200 \pm 3.4351$ years and age range between 21 to 38 year. Maximum $47.8 \%$ respondents were coming from Urban area. Besides maximum $44.9 \%$ respondents were belonging with housewife.

More than half of the patients belong to age group 25 to 29 years. In group A $50 \%$ and in Group B $63.6 \%$. Then second highest age group is 30 to 34 years, $35.3 \%$ in Group A and $27.3 \%$ in Group B. More than two third patients were housewife $71 \%$ in Group A and $81.8 \%$ in group B. more than two third patients $75 \%$ in Group A and $81.8 \%$ in Group B. the difference was not significant $(p>0.05)$ between two groups. BMI and follicle size are positively correlated but not significance, here $\mathrm{P}>0.05$.

The AMH is more sensitive and specific than follicle count as it reflects both preantral and small antral follicles. Similar findings Recovery was assessed at low, medium, and high concentrations for each internal standard. The mixture at each concentration was added to the FF matrix prior to the extraction or instrumental analysis. A recovery experiment was conducted in triplicate for quality control (QC) purposes. Recoveries were calculated using the peak area ratios of the standards spiked before extraction to the standard spiked before instrumental analysis. The results indicated that the recoveries ranged from $86.4 \%$ to $113.7 \%$ for the six internal standards at low, medium, and high concentrations. Therefore, the recovery rate of the detection method used was satisfactory [10].

Demonstrated results also shows the distribution of the study populations by clinical characteristics was observed that more than half $55.6 \%$ in group A and $63.6 \%$ in group B populations had primary subfertility. According to BMI level more than $74.2 \%$ in group $\mathrm{A}$ and $60 \%$ in group B were overweight. In Group A $19.4 \%$ were obese and $30 \%$ were obese in Group B. According to hirsutism FG score more than $70 \%$ had more than 60.The difference was not $(p>0.05)$ statistically significant. This result correlate to one study, in university of Nottingham UK did a study at fertility unit, Derby. It was a $\mathrm{T}$ a prospective cohort observational study included 60 anuovulatory women with PCOS received ovulation induction with CC between November2009 to March 2011.Primary study outcome was ovarian response, secondary was pregnancy. $35,(58 \%)$ ovulated during ist cycle of $\mathrm{CC}$. This number was $48(80 \%)$ when dose raised upto maximum $(150 \mathrm{mg} / \mathrm{d})$. Of the $187 \mathrm{cycle}$ Serum AMH concentrations were significantly (P .001) lower in responders (achieving ovulation) vs. nonresponders (mean SEM, 2.50 .1 vs $5.80 .7 \mathrm{ng} / \mathrm{mL}$, respectively) [11].

From regression analysis $\mathrm{R}$ denotes the correlation between predicted and observed serum LH. In our case, $R=0.390$. Since this is a positive correlation, our model predicts serum LH rather precisely. R square indicates the proportion of variance in Serum LH that can be "explained" by our two predictors. Here $\mathrm{R}$ square is 0.152 . The adjusted $\mathrm{r}$ square estimates the population $\mathrm{R}$ square for our model and thus gives a more realistic indication of its predictive power. Here adjusted $\mathrm{R}$ square is 0.106 . Similarly, serum AMH concentrations were significantly (P .046) lower in pregnant $(3.00 .4 \mathrm{ng} / \mathrm{mL})$ vs nonpregnant patients $(4.40 .5 \mathrm{ng} / \mathrm{mL})$. There was a significant $(\mathrm{P} .02)$ gradient increase of serum AMH levels with the increasing dose of $\mathrm{CC}$ required to achieve ovulation. The receiver-operating characteristic curve showed AMH to be a useful predictor of no ovulation (area under the curve, 0.809;.001) with a useful cutoff level of $3.4 \mathrm{ng} / \mathrm{mL}$. Ovulation and pregnancy rates were significantly higher $(97 \%, \mathrm{P} .001$, and $46 \%, \mathrm{P} .034)$ in patients with low AMH (3.4 $\mathrm{ng} / \mathrm{mL})$ vs women with $\mathrm{AMH} 3.4 \mathrm{ng} / \mathrm{mL}$ or greater (48\% and $19 \%)$.

According to correlation table of AMH with itself ( $\mathrm{r}=1)$, and the number of nonmissing observations for height $(\mathrm{n}=46)$. Correlation of AMH and Follicle Size $(r=-0.288)$, based on $n=46$ observations with pairwise nonmissing values. AMH and Follicle Size have a 
Iffana Azam et al; Sch J App Med Sci, Feb, 2021; 9(2): 241-247

statistically significant linear relationship $(r=-0.288, p$ $\leq 0.05$ ). The direction of the relationship is positive meaning that these variables tend to increase together. Similarly study conducted by one study in 2018 did this retrospective study included 100 patients were admitted to Ministry of Health Etlik Zubeyde Hanim Woman's Health Teaching and Research Hospital. All patients diagnosed with unexplained infertility had ovulation induction using $\mathrm{CC}$ followed by intrauterine insemination. The patients who developed at least one follicle of $>16 \mathrm{~mm}$ in diameter were considered as a positive ovarian response and had intrauterine insemination failed to develop at least a follicole and the patients who developed at least one follicle of $>16$ $\mathrm{mm}$ in diameter were considered as a positive ovarian response [12].

\section{Conclusion}

From this study it is easily understandable that AMH plays an important role to predict ovarian response to ovulation education in Polycystic Ovary Syndrome (PCOS) patients.

\section{REFERENCES}

1. Wilkes S, Chinn DJ, Murdoch A, Rubin G. Epidemiology and management of infertility: a population-based study in UK primary care. Fam Pract. 2009;26(4):269-274.

2. Salmassi A, Mettler L, Hedderich J, Jonat W, Deenadayal A, Von Otte S, Eckmann-Scholz C, Schmutzler AG. Cut-off levels of anti-mullerian hormone for the prediction of ovarian response, in vitro fertilization outcome and ovarian hyperstimulation syndrome. International journal of fertility \& sterility. $2015 \mathrm{Jul} ; 9(2): 157$.

3. Kriseman M, Mills C, Kovanci E, SangiHaghpeykar H, Gibbons W. Antimullerian hormone levels are inversely associated with body mass index (BMI) in women with polycystic ovary syndrome. J Assist Reprod Genet. 2015;32(9):1313-1316.

4. Tremellen K, Zander-Fox D. Serum anti-Mullerian hormone assessment of ovarian reserve and polycystic ovary syndrome status over the reproductive lifespan. Aust N Z J Obstet Gynaecol. 2015;55(4):384-389.

5. Aghssa MM, Tarafdari AM, Tehraninejad ES, et al. Optimal cutoff value of basal anti-mullerian hormone in iranian infertile women for prediction of ovarian hyper-stimulation syndrome and poor response to stimulation. Reprod Health. 2015;12:85.

6. El-Gharib MN, Mahfouz AE, Farahat MA. Comparison of letrozole versus tamoxifen effects in clomiphen citrate resistant women with polycystic ovarian syndrome. J Reprod Infertil. 2015;16(1):30-35.

7. Lamazou F, Genro V, Fuchs F, Grynberg M, Gallot V, Achour-Frydman N, Fanchin R, Frydman R. Serum AMH level is not a predictive value for IVF in modified natural cycle: analysis of 342 cycles. Journal de gynecologie, obstetrique et biologie de la reproduction. 2011 Mar 22;40(3):205-10.

8. El-Halawaty S, Rizk A, Kamal M, AboulHassan M, Al-Sawah H, Noah O, Al-Inany H. Clinical significance of serum concentration of antiMüllerian hormone in obese women with polycystic ovary syndrome. Reproductive biomedicine online. 2007 Jan 1;15(5):495-9.

9. Nakhuda GS, Chu MC, Wang JG, Sauer MV, Lobo RA. Elevated serum mullerian-inhibiting substance may be a marker for ovarian hyperstimulation syndrome in normal women undergoing in vitro fertilization. Fertil Steril. 2006;85(5):1541-1543.

10. Lee JR, Kim SH, Kim SM, Jee BC, Ku SY, Suh CS, Choi YM, Kim JG, Moon SY. Anti-Müllerian hormone dynamics during controlled ovarian hyperstimulation and optimal timing of measurement for outcome prediction. Human reproduction. 2010 Oct 1;25(10):2597-604.

11. Gnoth C, Schuring AN, Friol K, Tigges J, Mallmann P, Godehardt E. Relevance of antiMullerian hormone measurement in a routine IVF program. Hum Reprod. 2008;23(6):1359-1365.

12. Fanchin R, Mendez Lozano DH, Louafi N, AchourFrydman N, Frydman R, Taieb J. Dynamics of serum anti-Mullerian hormone levels during the luteal phase of controlled ovarian hyperstimulation. Hum Reprod. 2005;20(3):747-751. 